\title{
Proceedings of the Colloquium
}

\section{M arketing $\mathrm{H}$ orticultural Crops G lobally}

\begin{abstract}
held at the
89th Annual Meeting Honolulu, Hawaii

4 August 1992

Marketing and Economics Working Group; Gitrus Crops Working Group; Commercial Horticulture Working Group; Consumer Horticulture Working Group; Foriculture Working Group; Human Issues in Horticulture Working Group; Pomology Working Group; Intellectual Property Rights Working Group; International Horticultural Consultants Working Group; Nursery Orops Working Group; published by the American Society for Horticultural Science Alexandria, Virginia
\end{abstract}

\section{Colloquium Papers and Authors Presiding: Melvin P. Garber}

Marketing Horticultural Orops Gobally: Introduction and Perspective

M.P. Garber

Opportunities for Optimism: Marketing U.S. Horticultural Orops Gobally

H. Marc Cathey

Gosing the Gircle: Exporting Grapefruit to Japan Gordon E Hunt and Mohamed A. Ismail

1989-90 Vegetable Production in Mexico for Export to the United States

J.F. Gomez
Export Marketing of Fresh Fruits in New Zealand Donald H. Turner and Robin G Brumfield

Gobal Horticulture and the Quest for Seed Varieties Francoic Korn

Intellectual Property Rights in a Gobal Market Robert J. Jondle

Strategic Management in Foriculture William H. Carlson

Horticulture and the Global Market

Ricardo E Gomez and Dixon D. Hubbard 